\title{
Gastrointestinal symptoms in atopic eczema
}

\author{
Carlo Caffarelli, Giovanni Cavagni, Franca M Deriu, Paola Zanotti, David J Atherton
}

\begin{abstract}
Aims-To determine the prevalence of gastrointestinal symptoms in children with eczema and the association of such symptoms with the extent of eczema or skin prick test results.

Methods-Sixty five children with atopic eczema and a control group matched for age and sex were recruited. Their parents completed a questionnaire about the children's gastrointestinal symptoms. The children's skin was examined; their weight, height, and abdominal circumference were measured; and skin prick tests were carried out.

Results-Gastrointestinal symptoms, especially diarrhoea, vomiting, and regurgitation, were more common in the children with eczema. Diarrhoea appeared to be associated with the ingestion of specific foods. Gastrointestinal symptoms were related to diffuse eczema and positive skin prick tests to foods. There was no anthropometric differences between the patient and control groups.

Conclusions-A gastrointestinal disorder is common in children with eczema, especially with diffuse distribution. This may be responsible for substantial symptoms and may play a part in the pathogenesis of the disease and in the failure to thrive with which it is sometimes associated. (Arch Dis Child 1998;78:230-234)
\end{abstract}

Keywords: atopic eczema; gastrointestinal symptoms

Minor gastrointestinal abnormalities have been reported in children with atopic eczema in several studies. These have included histological and functional abnormalities of the gastric epithelium, ${ }^{1}$ mild degrees of jejunal villous atrophy with eosinophil infiltration and oedema of the lamina propria, ${ }^{1{ }^{2}}$ low jejunal mucosal IgA plasma cell counts, ${ }^{3}$ and increased IgE immunoreactive cells in the duodenal mucosa. ${ }^{4}$ There have also been a number of reports of increased gastrointestinal permeation by inert markers such as lactulose and rhamnose. ${ }^{5}$

In addition, children with eczema who had been given foods as a challenge test during the investigation of food allergy had gastrointestinal reactions. ${ }^{6-10}$ On reviewing published papers, however, we were unable to find any studies which examined the prevalence of gastrointestinal symptoms in children with atopic eczema.

We therefore decided to undertake a questionnaire survey of children with atopic eczema to estimate the prevalence and type of gastrointestinal symptoms. We also studied the associ- ation between the finding of gastrointestinal symptoms and the extent of eczema or skin prick test results.

\section{Patients and methods}

PATIENTS

Over a period of four months the parents of all children attending the paediatric clinic of the University Hospital of Parma for the treatment of atopic eczema were invited to take part in a questionnaire study. The study group comprised 65 children less than 14 years of age who met the criteria of Hanifin and Rajka ${ }^{11}$ for the diagnosis of atopic eczema.

Sixty five healthy children were recruited as controls. The recruitment of children aged 1-14 years was undertaken at routine annual school health examinations. Infants were recruited at a vaccination clinic. None of these children had either active atopic eczema on examination or a history of previous atopic eczema. These children were always accompanied by a parent whose permission was sought for participation in the study.

\section{METHODS}

\section{Questionnaire}

Consenting parents completed a questionnaire in the clinic. This was simple in design. Questions about eczema included the age of onset and whether it appeared to be provoked or worsened by the ingestion of particular foods. These questions were excluded from the questionnaires given to controls. The questions put to the two groups were about the presence or absence of a history of atopic disease in parents or siblings and the presence of atopic symptoms (asthma, allergic rhinitis, or conjunctivitis) and gastrointestinal symptoms present in the children. Parents were also asked whether any food was excluded from the diet of their child and why.

The following information was sought in relation to gastrointestinal symptoms. A history of infantile colic was elicited by asking whether, in the first weeks of life, the infant had cried for periods exceeding 20 minutes, especially in the evening, with flexing of limbs, perhaps associated with excessive flatulence, for which there was no apparent cause and which could not be relieved by feeding or comforting. A history of abdominal pain was sought only in children over 3 years of age. The occurrence of abdominal distension was sought by asking "has your child's abdomen ever been swollen?" Eructation and flatulence were identified by asking whether the child had frequently expelled gas forcibly through their mouth or anus, respectively. A history of diarrhoea was elicited by asking parents whether their child had ever had three or more liquid or semiliquid motions in a 
Table 1 Age, sex, height, weight, and atopic history in the atopic eczema and control groups

\begin{tabular}{|c|c|c|c|c|}
\hline & $\begin{array}{l}\text { Atopic eczema group } \\
(n=65)\end{array}$ & Control group $(n=65)$ & $p$ Value & $95 \% C I$ \\
\hline Mean (range) age (years) & 3.55 ( 6 months -14 years) & 3.65 ( 6 months -14 years) & NS & - \\
\hline Male/female & $40 / 25$ & $40 / 25$ & NS & - \\
\hline Mean (range) height $(\mathrm{cm})$ & $96.25(65-170)$ & $98.30(62-171)$ & NS & - \\
\hline Mean (range) weight (kg) & $17.52(7.0-68.5)$ & $20.51(5.4-68.0)$ & NS & - \\
\hline No (\%) with atopic family history & $46(71)$ & $19(29)$ & $<0.001$ & 0.256 to 0.564 \\
\hline No (\%) with other atopic symptoms & $24(37)$ & $3(5)$ & $<0.001$ & 0.125 to 0.445 \\
\hline
\end{tabular}

NS = not significant.

24 hour period ${ }^{12}$ which were not overtly caused by an infection (that is accompanied by fever or diagnosed by a doctor as gastroenteritis). Constipation was identified by the question "has your child ever defecated less than once in any three day period?" Vomiting was defined as "the forceful expulsion of gastric contents which was not overtly caused by an infection (that is accompanied by fever or diagnosed by a doctor as gastroenteritis)". Regurgitation was defined as "the passive reappearance in the mouth or flow out of the mouth of food that had previously been swallowed".

Parents were also asked when any symptoms had first appeared and whether they occurred after the ingestion of particular foods. Symptoms were considered current if they had occurred during the previous week.

\section{Examination}

Weight and height were measured in all the children. The measurement of abdominal circumference, both at the most caudal point of the eleventh rib and at the umbilicus, was also performed to verify our impression that children with atopic eczema have large abdomens. We were keen to seek any association between the presence of gastrointestinal symptoms and the extent of a child's eczema. Each child's eczema was therefore classified as follows: (a) distribution-diffuse (either morbilliform or erythrodermic) or predominantly localised (either predominantly flexural, nummular, predominantly facial, or other patterns, not predominantly flexural); and (b) overall severity - mild, moderate, moderate-severe, severe.
Children with atopic eczema underwent skin prick tests with commercial extracts $(1: 10 \mathrm{w} / \mathrm{v}$; Bayropharm, Milan, Italy) of hens' egg, egg white, egg yolk, whole cows' milk, casein, $\beta$-lactoglobulin, $\alpha$-lactoalbumin, goats' milk, pea, cereals, bean, peanut, banana, pear, peach, apple, cherry, soy, tomato, spinach, potato, carrot, beef, pig, lamb, chicken, rabbit, cod, tuna, salmon, Dermatophagoides pteronyssinus and farinae, histamine $10 \mathrm{mg} / \mathrm{ml}$, and negative control (diluent). The test was considered positive if it elicited a weal at least $3 \mathrm{~mm}$ greater than the control and more than half the size of the weal produced with histamine.

\section{Statistics}

We sought a $50 \%$ increase in gastrointestinal symptoms, the expected frequency of which in the population is $55 \%$, in the group with atopic eczema. A sample size of 55 gives a $90 \%$ power of detecting a difference at $5 \%$ significance.

Age and anthropometric measurements were compared by analysis of variance. $\chi^{2}$ Analysis, with Yates's correction, or Fisher's exact test were used to test differences between variables with dichotomous data with the $95 \%$ confidence interval (CI) for the difference in proportions being calculated when appropriate. Results were considered statistically significant at $\mathrm{p}<0.05$.

\section{Results}

Every questionnaire was fully completed. There were 40 boys and 25 girls in each of the eczema and the control groups. There was no significant difference in age, height, and weight between the atopic eczema and the control

Table 2 Cumulative frequencies (number (\%)) and current prevalences (number (\%)) of gastrointestinal symptoms in 65 children with atopic eczema (AE) and 65 controls $(C)$

\begin{tabular}{|c|c|c|c|c|c|c|c|}
\hline Symptom & Group & $\begin{array}{l}\text { Cumulative } \\
\text { frequency }\end{array}$ & $p$ Value & $95 \% C I$ & $\begin{array}{l}\text { Current } \\
\text { prevalence }\end{array}$ & p Value & $95 \% C I$ \\
\hline Infantile colic & $\mathrm{AE}$ & $30(46)$ & NS & - & 0 & NS & - \\
\hline Abdominal pain $(n=29)$ & $\begin{array}{l}\mathrm{C} \\
\mathrm{AE} \\
\mathrm{C}\end{array}$ & $\begin{array}{l}32(49) \\
1(3) \\
7(24)\end{array}$ & NS & - & $\begin{array}{l}0 \\
5(17) \\
0\end{array}$ & NS & - \\
\hline Abdominal distension & $\begin{array}{l}\mathrm{AE} \\
\mathrm{C}\end{array}$ & $\begin{array}{l}11(17) \\
5(8)\end{array}$ & NS & - & $\begin{array}{l}7(11) \\
1(2)\end{array}$ & NS & - \\
\hline Eructation & $\begin{array}{l}\mathrm{AE} \\
\mathrm{C}\end{array}$ & $\begin{array}{l}5(8) \\
0\end{array}$ & NS & - & $\begin{array}{l}5(8) \\
0\end{array}$ & NS & - \\
\hline Flatulence & $\begin{array}{l}\mathrm{AE} \\
\mathrm{C}\end{array}$ & $\begin{array}{l}12(18) \\
6(9)\end{array}$ & NS & - & $\begin{array}{l}8(12) \\
2(3)\end{array}$ & NS & - \\
\hline Diarrhoea & $\begin{array}{l}\mathrm{AE} \\
\mathrm{C}\end{array}$ & $\begin{array}{l}20(31) \\
0\end{array}$ & $<0.001$ & 0.191 to 0.409 & $\begin{array}{l}7(11) \\
0\end{array}$ & NS & - \\
\hline Constipation & $\begin{array}{l}\mathrm{AE} \\
\mathrm{C}\end{array}$ & $\begin{array}{l}12(18) \\
15(23)\end{array}$ & NS & - & $\begin{array}{l}6(9) \\
9(14)\end{array}$ & NS & - \\
\hline Vomiting & $\begin{array}{l}\mathrm{AE} \\
\mathrm{C}\end{array}$ & $\begin{array}{l}12(18) \\
2(3)\end{array}$ & $<0.01$ & 0.054 to 0.246 & $\begin{array}{l}2(3) \\
2(3)\end{array}$ & NS & - \\
\hline Regurgitation & $\begin{array}{l}\mathrm{AE} \\
\mathrm{C}\end{array}$ & $\begin{array}{l}25(38) \\
11(17)\end{array}$ & $<0.025$ & 0.021 to 0.299 & $\begin{array}{l}7(11) \\
1(2)\end{array}$ & NS & - \\
\hline \multirow[t]{2}{*}{$\begin{array}{l}\text { Any gastrointestinal } \\
\text { symptom }\end{array}$} & $\mathrm{AE}$ & $54(83)$ & $<0.001$ & 0.133 to 0.407 & $27(42)$ & $<0.001$ & 0.113 to 0.387 \\
\hline & $\mathrm{C}$ & $37(57)$ & & & $11(17)$ & & \\
\hline
\end{tabular}

NS = not significant. 
Table 3 Extent of atopic eczema related to gastrointestinal symptoms

\begin{tabular}{lllll}
\hline & \multicolumn{2}{l}{ Gastrointestinal symptoms } & & \\
\cline { 2 - 3 } $\begin{array}{l}\text { Children with atopic } \\
\text { eczema }\end{array}$ & $\begin{array}{l}\text { No (\%) with } \\
(n=54)\end{array}$ & $\begin{array}{l}\text { No (\%) without } \\
(n=11)\end{array}$ & p Value & $95 \%$ CI \\
\hline $\begin{array}{l}\text { Distribution } \\
\quad \begin{array}{l}\text { Diffuse } \\
\text { Localised }\end{array}\end{array}$ & $17(31)$ & 0 & $<0.05$ & 0.187 to 0.433 \\
$\begin{array}{l}\text { Severity } \\
\text { Mild/moderate }\end{array}$ & $37(69)$ & $11(100)$ & & \\
$\quad \begin{array}{l}\text { Moderate-severe } \\
\text { Severe }\end{array}$ & $19(35)$ & $4(36)$ & NS & - \\
\hline
\end{tabular}

NS $=$ not significant. tion. Several other gastrointestinal symptoms were reported with increased frequency in the children with atopic eczema, although statistical significance was not reached; these included abdominal pain, distension, eructation, and flatulence. There was no suggestion of any increase in infantile colic and constipation.

In $36(67 \%)$ of the 54 children with atopic eczema and gastrointestinal symptoms, the onset of the latter preceded the onset of eczema. Gastrointestinal symptoms were more common in the children with diffuse eczema (table 3). No association was found between the severity of eczema and the occurrence of gastrointestinal symptoms.

The mean age of onset of gastrointestinal symptoms was 11.2 months for the children with atopic eczema (range 15 days to 96 months) and 4.12 months (range 15 days to 74 months) for the control group; the difference was statistically significant $(\mathrm{p}<0.05)$.

A history of gastrointestinal symptoms after the ingestion of particular foods was more likely in children with atopic eczema (24 of 54 children; 44\%) than in the control group (eight of $37 ; 22 \%$ ) ( $p<0.05,95 \%$ CI 0.045 to 0.415$)$.

The only specific gastrointestinal symptom in the group with atopic eczema which was significantly associated with the ingestion of particular foods was diarrhoea ( $p<0.05,95 \%$ CI 0.051 to 0.209 ); such an association was present in nine of $20(45 \%)$ children with this symptom. There was no association between gastrointestinal symptoms and sex or age grouping $(<1 v>1$ year; $<3 v>3$ years; $<5 v>5$ years).

In the children with atopic eczema there was a significant association between the occurrence of any gastrointestinal symptoms, except colic and constipation, and the presence of atopic symptoms other than eczema (22 of 45 children $v 0$ of $11 ; \mathrm{p}<0.01,95 \%$ CI 0.335 to 0.625 . A relation between any gastrointestinal symptoms, except colic and constipation, and sex or age grouping $(<1 v>1$ year; $<3 v>3$ years; $<5 v>5$ years) was not observed in such children. There was no significant difference in height, weight, umbilical circumference, or specifically diarrhoea, vomiting, and regurgita-

Table 4 Positive skin prick tests (SPT) to foods and reported rates of gastrointestinal symptoms in children with atopic eczema

\begin{tabular}{|c|c|c|c|c|}
\hline Children with atopic eczema & $\begin{array}{l}\text { No (\%) with at least one positive } \\
\text { SPT to food }(n=35)\end{array}$ & $\begin{array}{l}\text { No (\%) with negative } \\
\text { SPT to food }(n=30)\end{array}$ & $p$ Value & $95 \% C I$ \\
\hline Any gastrointestinal symptom & $34(97)$ & $20(67)$ & $<0.005$ & 0.110 to 0.510 \\
\hline Current & $19(54)$ & $8(27)$ & $<0.005$ & 0.054 to 0.506 \\
\hline Infantile colic & $18(51)$ & $12(40)$ & NS & - \\
\hline Current & 0 & 0 & NS & - \\
\hline Abdominal pain & $6(40)(n=15)$ & $1(7)(n=14)$ & NS & - \\
\hline Current & $4(27)$ & $1(7)$ & NS & - \\
\hline Distention & $6(17)$ & $3(10)$ & NS & - \\
\hline Current & $4(11)$ & $3(10)$ & NS & - \\
\hline Eructation & $3(9)$ & $2(7)$ & NS & - \\
\hline Current & $3(9)$ & $2(7)$ & NS & - \\
\hline Flatulence & $8(23)$ & $4(13)$ & NS & - \\
\hline Current & $6(17)$ & $2(7)$ & NS & - \\
\hline Diarrhoea & $16(46)$ & $4(13)$ & $<0.001$ & 0.117 to 0.523 \\
\hline Current & $7(20)$ & 0 & $<0.05$ & 0.068 to 0.332 \\
\hline Constipation & $8(23)$ & $4(13)$ & NS & - \\
\hline Current & $4(11)$ & $2(6)$ & NS & - \\
\hline Vomiting & $11(31)$ & $1(3)$ & $<0.01$ & 0.127 to 0.433 \\
\hline Current & $2(6)$ & 0 & NS & - \\
\hline Regurgitation & $16(46)$ & $9(30)$ & NS & - \\
\hline Current & $5(14)$ & $2(7)$ & NS & - \\
\hline
\end{tabular}

NS = not significant. 
11 th rib circumference between children with and without any gastrointestinal symptoms or abdominal disorders other than infantile colic and constipation.

SKIN PRICK TEST RESULTS

No child with atopic eczema had a positive result on the control skin prick test. Thirty nine $(60 \%)$ of the children with eczema had at least one positive skin prick test. In 35 (54\%) of the children with atopic eczema the skin prick test was positive to at least one food antigen. Twenty four $(37 \%)$ had a positive skin prick test to whole egg (22 (34\%) to egg yolk, 18 $(28 \%)$ to egg white), $14(22 \%)$ to whole cows' milk or one protein fraction $(11(17 \%)$ to whole cows' milk, seven (11\%) to casein, six $(9 \%)$ to $\beta$ lactoglobulin, five $(8 \%)$ to $\alpha$ lactoalbumin), $12(18 \%)$ to peanuts, eight $(12 \%)$ to lamb, seven $(11 \%)$ to pig, seven to beef, six $(9 \%)$ to potato, six to pea, six to oat, five $(8 \%)$ to wheat, five to bean, four $(6 \%)$ to tomato, four to chicken, four to rabbit, three $(5 \%)$ to rice, three to barley, two $(3 \%)$ to salmon, two to tuna, two to soy, two to carrot, one $(2 \%)$ to cherry, one to plum, and one to cod. Eleven $(17 \%)$ children had a positive skin prick test to at least one type of dust mite. In the group with atopic eczema there was a significant association between a positive skin prick test to at least one food and any gastrointestinal symptom, diarrhoea, and vomiting (table 4).

\section{Discussion}

This study is the first to relate gastrointestinal symptoms and atopic eczema. We have determined that gastrointestinal disorders, particularly diarrhoea, regurgitation, and vomiting, are significantly more common in children with atopic eczema than in control children.

Previous studies have offered only an indirect indication of an association between abdominal disorders, especially vomiting and diarrhoea, and atopic eczema by documenting either (a) the development of gastrointestinal symptoms in children with eczema after challenge with foods to which they show immediate hypersensitivity, ${ }^{6-8}$ or (b) the occasional concurrence of eczema and gastrointestinal symptoms in children investigated for cows' milk allergy, both in their history and after a challenge with cows' milk. ${ }^{9}{ }^{10}$ Our study differs from these others in that we have characterised the type and prevalence of gastrointestinal symptoms in children with atopic eczema.

Among the gastrointestinal symptoms associated with atopic eczema, regurgitation is not specifically mentioned in any previous study ${ }^{6-10}$; this might reflect the difficulty in differentiating regurgitation from vomiting, especially in very young infants. On the other hand, previous studies have shown that both regurgitation and atopic eczema are clinical manifestations of a cows' milk allergy. ${ }^{13}{ }^{14} \mathrm{We}$ have observed that the frequency of infantile colic was not increased in children with atopic eczema. This finding seems to contradict the association

\section{Key messages}

- Gastrointestinal symptoms are common in children with atopic eczema

- Gastrointestinal symptoms are more frequent in children with extensive skin disease

- Gastrointestinal symptoms may be troublesome and should not be ignored, albeit there is no association with failure to thrive

- An aetiological role for foods may be suspected in some of these children

between colic and atopy, which is considered questionable. ${ }^{1516}$

We believe that our findings are consistent with the existence of an atopic gastroenteropathy in a high proportion of children with atopic eczema, especially with a diffuse distribution. As we have found that gastrointestinal symptoms are generally not associated with a failure to thrive, they are likely to be ignored. We believe, however, that symptoms of this type should be adequately considered because they may be troublesome, may affect activity, and may be a source of substantial anxiety to parents.

Reports of minor morphological abnormalities of the gastrointestinal $\operatorname{tract}^{1-3}$ and of increased gastrointestinal permeability to macromolecules ${ }^{17}$ and inert disaccharides ${ }^{5}$ provide support for the view that the gastrointestinal tract is often abnormal in children with eczema. Severe enteropathy has also occasionally been reported. ${ }^{18}$ It remains unclear, however, whether this disorder is associated primarily with atopic eczema or with atopic status more generally. There is some support for the view that gastrointestinal abnormalities are common in children with all atopic diseases. ${ }^{1}$

The possible mechanisms underlying such a gastroenteropathy are also unclear. Reactions to food antigens contribute to the pathogenesis of atopic eczema. ${ }^{1319}$ In infants with atopic eczema, a cows' milk allergy is associated with an enhanced eosinophil cationic protein and tumour necrosis factor- $\alpha$ in the faeces, indicating intestinal allergic inflammation. ${ }^{20}$ In our study, a role for dietary antigens in the onset of abdominal disorders is supported by the relatively frequent association between gastrointestinal symptoms and the ingestion of a particular food, and a positive skin prick test to food.

The issue also arises whether gastrointestinal abnormalities could precede atopic eczema and perhaps play a part in the aetiology of the skin disease by allowing allergic sensitisation as a result of increased antigen entry through the damaged mucosa. In this respect it may be relevant that gastrointestinal symptoms were reported to have preceded evidence of skin disease in most of our children with atopic eczema. 
The role of food allergy in the pathogenesis of gastrointestinal symptoms in children with eczema can be clarified by prospective studies which investigate the development of such symptoms in infants in association with different infant formulas. It can be established only by an effective elimination diet and positive oral challenge with dietary allergens. Another possibility is that substances released into the circulation by inflamed eczematous skin could provoke symptoms in the gastrointestinal tract.

The gastrointestinal symptoms found in a high proportion of children with atopic eczema indicate that more general disorders than previously thought take place in most of these patients. Children with gastrointestinal symptoms were frequently characterised by having a diffuse distribution of eczema and a positive skin prick test to foods. We suggest that further studies on the aetiology of atopic eczema should be based on the separate grouping of patients with gastrointestinal symptoms. If such a subset exists, its further investigation may provide clues about the identification of children who would benefit from the avoidance of food allergens and may help us to understand why some children with atopic eczema fail to thrive. ${ }^{2122}$

1 Kokkonen J, Simila S, Herva R. Gastrointestinal findings in

atopic children. Eur $\mathcal{F}$ Pediatr 1980;134:249-54.
2 McCalla R, Savilahti E, Perkkio M, et al. Morphology of the McCalla R, Savilahti E, Perkkio M, et al. Morphology of the
jejunum in children with atopic eczema due to food allergy. jejunum in children with

3 Sloper KS, Brook CGD, Kingston D, et al. Eczema and atopy in early childhood; low IgA plasma cell counts in the jejunal mucosa. Arch Dis Child 1981;56:939-42.

4 Kalimo K, Lammintausta K, Klemi P, et al. Mast cells and IgE in intestinal mucosa in adult atopic dermatitis patients. Br F Dermatol 1988;119:579-85.

5 Pike M, Heddle RJ, Boulton P, et al. Increased intestinal permeability in atopic eczema. F Invest Dermatol 1986;86:
6 Sampson HA, Albergo R. Comparison of results of skin tests, RAST, and double-blind, placebo-controlled food challenges in children with atopic dermatitis. F Allergy Clin Immunol 1984;74:26-33.

7 Sampson HA, McCaskill CC. Food hypersensitivity and atopic dermatitis: evaluation of 113 patients. $\mathcal{F}$ Pediatr 1985;107:669-75.

8 Burks WA, Mallory SB, Williams LW, et al. Atopic dermatitis: clinical relevance of food hypersensitivity reactions. F Pediatr 1988;113:447-51.

9 Jakobsson I, Lindberg T. A prospective study of cow's milk protein intolerance in Swedish infants. Acta Paediatr Scand 1979;69:853-9.

10 Hill DJ, Firer MA, Shelton MJ, et al. Manifestations of milk allergy in infancy: clinical and immunologic findings. $f$ Pediatr 1986;109:270-6.

11 Hanifin JM, Rajka G. Diagnostic features of atopic dermatitis. Acta Dermatol Venereol (Stockh) 1980;suppl 92:44-7.

12 Baqui $\mathrm{AH}$, Black RE, Yunus MD, et al. Methodological issues in diarrhoeal disease epidemiology: definition of diarrhoeal episodes. Int f Epidemiol 1991;20:1057-63.

13 Atherton DJ, Sewell M, Soothill JF, et al. A double-blind, controlled crossover trial of an antigen avoidance diet in atopic eczema. Lancet 1978;i:401-3.

14 Forget P, Arends JW. Cow's milk protein allergy and gastrooesophageal reflux. F Pediatr 1985;144:298-300.

15 Forsyth BW. Colic and the effect of change in formulas: a double-blind, multiple-cross-over study. F Pediatr 1989; 115:521-6.

16 Hill DJ, Hudson IL, Sheffield LJ, et al. A low allergen diet is a significant intervention in infantile colic: results of a a significant intervention in infantile colic: results of a 886-92.

17 Paganelli R, Levinsky RJ, Brostoff J, et al. Immune complexes containing food proteins in normal and atopic subjects after oral challenge and effect of sodium cromoglycate on antigen absorption. Lancet 1979;i:1270-

18 Jenkins HR, Walker-Smith JA, Atherton DJ. Protein-losing enteropathy in atopic dermatitis. Pediatr Dermatol 1986;3: $125-9$.

19 Burks AW, Mallory SB, Williams LW, et al. Atopic dermatitis: clinical relevance of food hypersensitivity reactions. F Pediatr 1988;113:669-75.

20 Majamaa $\mathrm{H}$, Miettinen A, Laine $\mathrm{S}$, et al. Intestinal inflammation in children with atopic eczema: faecal eosinophil cationic protein and tumor necrosis factor- $\alpha$ as esinophil cationic protein and $\alpha$ as 1996;26:181-7.

21 Pike MG, Chang CL, Atherton DJ, et al. Growth in atopic eczema: a controlled study by questionnaire. Arch Dis Child 1989;64:1566-9.

22 Massarano AA, Hollis S, Devlin J, et al. Growth in atopic eczema. Arch Dis Child 1993;68:677-9. 